\title{
Research on Building Qinhuangdao Characteristic Community Home Endowment System under the "Four Strengths; Four Possessions" Party Building Mechanism
}

\author{
Liu Jingjing, Yuan Hejing \\ Environmental Management College of China, Qinhuangdao Hebei 066000, China
}

Keywords: "Four Strengths; Four Possessions" community; Home endowment; Qinhuangdao

\begin{abstract}
Endowment problems brought by an aging population are a global problem. This paper analyzes significance and current situation of Qinhuangdao community home endowment enterprise development, argues that the construction of community home endowment center should be taken as an important part of the construction of " "Four Strengths; Four Possessions" " service at the grass-roots level party organizations, puts forward countermeasures and suggestions from strengthening the investment and infrastructure construction, mobilizing community resources, strengthening the construction of organization and team, and the introduction of social forces to build Qinhuangdao features community home endowment brand under the framework of "Four Strengths; Four Possessions" party construction mechanism.
\end{abstract}

\section{Introduction}

At present, the contradiction between the increasing of elderly population in our country and pension system is growingly deepened. With the in-depth development of the party's mass line education activities, how to solve people's most concerning and the most pressing issues are the focal point of party committees at all levels and party organizations at the grass-roots level while carrying out work. Qinhuangdao in Hebei province since 2013, the municipal party committee has carried out "“Four Strengths; Four Possessions"" service-oriented party organizations construction work at the grass-roots level which created new way of thinking for party construction, and provided a good opportunity and platform to enhance the level of urban community endowment, occupy home work, and create a new situation for home endowment enterprise.

\section{Community Home Endowment is the Effective Way to Solve the Problem of Urban Residents' Endowment}

When 60 years of age or older population quantity is more than $10 \%$, or 65 years of age or older population accounts for over $7 \%$ of the total population, it is said that the country or the region has entered an aging society. Aging society in our country already has more than 20 years history, and aging degree increases year by year. According to the Development of Chinese Aging "Twelfth Five-year" Plan, "in 2015, China's aging population will reach 221 million, which will be 16\% of the population." (1) From the scope of Qinhuangdao, in 3 million permanent residents, there is an ageing population of 472000 people, accounting for $15.8 \%$, which is in the national average. The situation is more serious, and it is also very representative in the three or four line city. At present, the main body of China's cities endowment patterns is still traditional family endowment and institutions such as nursing home endowment. However, these two kinds of models own clear defects:

First, Traditional family pension mode is increasingly weakened. With the development of society and economy, the traditional family structure changes greatly. Since the implementation of family planning, China urban family size is reduced gradually. With the deepening of industrialization and urbanization, social mobility and intergenerational separation phenomenon lead to increased empty nest family. According to the survey, there are more than 50\% of the total urban and rural empty-nest 
families in China, while some large and medium cities are as high as $70 \%$. The traditional family pension mode is pressed, and quite a number of young people have been overtaxed.

Second, institution endowment development is increasingly of bottleneck. At present, in addition to the family pension, institutional pension occupies an important position, and has characteristics such as business scale and professional service. Institution endowment patterns at the same time have bottlenecks like high cost, less equipment, and shortage of professionals. At present, developed countries provide institutional endowment beds to around 5\% to $7 \%$ of the total demand population. Because our country's heavy population and uneven development, over the years, the proportion has been below $2 \%$, which is far to adapt to the demand. And influenced by factors such as traditional ideas, many old people are reluctant to leave their homes because of kinship, geopolitical factors. The bottleneck of the concept is difficult to break through market and administrative means.

Community endowment patterns can effectively solve the above questions. It takes the community as a platform; integrates all kinds of service resources; provides systematic repast for the old men, cleaning, bathing, health care, entertainment and other services. The elderly live at home, while they can enjoy the service system, professional pension life, realize the old has supporters, and have old-aged providing. This service mode solves the problem of shortages of traditional family endowment service, and the traditional concept of indifferent and block affection in nursing home endowment, which recognized by the old-age work departments at all levels.

\section{Street Community Party Building is the Inner Motive Power of Community Home Endowment Development}

\section{A. The connotation of street community party building}

"Street community party construction is an important part of the construction of party organizations at the grass-roots level, and plays a leadership role as the core in the new period urban community party organizations, organizes, coordinates and guides various types of grass-roots party organizations and party members within their respective jurisdictions, and carries out the sum of all the regional, mass organizations, social and public welfare work and activities. Community party building field is very wide, and the most prominent is the embodiment of the cohesive forces on the function, service to the masses, and harmony promoting.

\section{B. The significance of street community party construction on the development of community home endowment}

The central and local party committees at all levels attach great importance to street community party construction. First national community party construction advance meeting took place in Qinhuangdao, and Haigang district social work was awarded the "First-class community party building" plaque by Chinese association. The region culture road neighborhood office was awarded "Civilized harmonious community building demonstration project - community party building Demonstration Street". In 2012, Hubei provincial party committee organization department held a seminar of community party building projects in Qinhuangdao. It is visible that Qinhuangdao has a more solid foundation for the streets community party building, and has strong organization guarantee in carrying out community home endowment. Especially, the "“Four Strengths; Four Possessions"" service-oriented party organizations at the grass-roots level creation activities provide a rare opportunity to strengthen this work.

First of all, it will promote the party committees and governments at all levels to pay more attention to community home endowment. There is no denying the fact that, because of the large endowment job involvement, difficulties to implement, not obvious short-term economic efficiency, some local party committee governments have yet to put it into the important position in the field of economic and social development. Community home endowment becomes an important gripper for party committees at all levels basic party, which will make the work into the view of local party and government leadership, and organization department. This helps the advancing of implementation category, and promotes a greater increase on the strength than simple business departments. 
Second, it will promote community home endowment normalization, standardization, and improve service quality. In street community party construction service form, incorporate community home endowment with community party member masses activity places construction, difficult members mass support as equally important position to promote community employment and make it to achieve normalized operation, get more policy, manpower and material resources, financial support, and promote community home endowment work level and service quality.

Again, this will promote community home endowment form and content innovation. It can be said that innovation is the soul of primary level. It is not only the content innovation of party construction, but the innovation of work form. It is innovation the driving force to make the grass-roots party construction work constantly. Complete community home endowment built is not that simple as canteen and chess, but needs constant explore and perfect to make endowment services more thoughtful and humane. Make street community home endowment into street community party construction system provides a reliable guarantee in achieving and perfecting the innovation of form and content.

\section{Street community home endowment service should be an integral part of community party building work.}

To party committees at all levels, to do a good job in pension, especially community home endowment is an important category of street community party construction work, and is also very necessary. First of all, this is direct embodiment of party's mass line practice. Old people are an important force in community building. A considerable portion of the residents of the community is the old. Due to the elderly staying at home for a long time with relatively abundant time and higher participation community construction enthusiasm, the elderly is an indispensable force in community organization and participation of various community activities and their demand for community service are the most urgent. Second, it is the common desire of community residents. Perfect community endowment can not only benefit the elderly, but other family members. Pension problems are concerned because the crack is difficult. Do good jobs in community home endowment can ease the contradictions among the people, safeguard social harmony and stability, and enhance the masses between the relationships greatly. Third, it is advantageous to street community party construction with lots of bright spots. While community home endowment issues a new measure or adds a new service project, not only the elderly and their families are benefited, also reflects the new measures of grass-roots party organizations in the service for the people, which reflects grass-roots party construction innovation and bright spot.

\section{“Four Strengths; Four Possessions” Party Building Mechanism Should be the Important Basis of Community Home Endowment}

\section{A. The basic content of "Four Strengths; Four Possessions"}

18th CPC National Congress puts forward important argument like "the Party's construction is to serve the masses, and the main task is to work for the masses", which is the important rule followed by the Party's construction at the primary level. Qinhuangdao took "Four Strengths; Four Possessions" (" Four Strengths: the ability to organize the masses, strong ties with the masses, strong condensation ability, guarantee the masses rights; Four Possessions: a wide variety of service platform, non-ferrous service carrier, the varieties of the service team and normalized service mechanism(3)" as the standard, fully launched the service party organizations creation activities at the grass-roots level, actively explore and practice regulation of function orientation, characteristics, working method and path in various fields such as in the countryside in the city, community, government agencies, enterprises, and colleges and universities.

In particular, the "Four Strengths; Four Possessions" plays outstanding performance role in all levels of party committee, party organizations at the grass-roots level which covers full in various industries, various areas; establish smooth ties with the masses channels, a harmonious relationship with masses, do it effectively, visit very wide, make it solid with good solution; One thousand ways to 
help the masses solve difficulties, and maintain the fundamental interests of the masses; Build comprehensive service system at the grass-roots level, increase the fiscal investment, provide strong support and guarantee for service to the masses. "Four Strengths; Four Possessions" outstanding performance in a wide variety of service platform, build five major service platform "entrepreneurial rich platform, information network platform, poverty alleviation, affairs agent platform, convenient service platform". Especially for poverty alleviation platform, classify and build difficult people, sick, left-behind children, migrant workers and other special groups information to timely provide necessary protection services for the masses; have a characteristic service carrier to distinguish five key areas between rural and community, organs, enterprises, window units and service industry, and in the community, carry out pair build to build community "10 minutes service circle"; Has varieties of service team, the construction of " party organization grass-roots team leader, party members and cadres, convenient service team and volunteers" four teams. According to the requirements of "public welfare, reveal professional", create convenient service team with capable personnel, wide cover, clear functions and comprehensive service; have normalized service mechanism, perfect five mechanisms "public opinion collection mechanism, leading contact mechanism, public commitment mechanism, evaluation mechanism, and guarantee service mechanism". Improving the service system guarantees capital source for the local people, places, etc. to promote service safeguard masses institutionalized, standardized and normalized.

\section{B. "Four Strengths; Four Possessions" catches the point of community endowment problems}

First, it points out the insufficient attention to community home endowment. Rural and community are the two largest fields at the primary level of party construction. As mentioned above, in street community party building work, solve the problem of community endowment has increasingly become an important content, and plays "extremely important" role. As the best model in urban pension, community home endowment in the future will become the important carrier of community CPC party construction, and will gain more and more attention of party committees and governments at all levels.

Second, it points out the lack of venue construction funds. In community home endowment, a big important condition is to form a complete set of hardware, including the place of the old recreational activities, dining hall, community medical institutions, etc., which requires government pretty input. Relying on endowment department in charge of work calls for power co., LTD. Include community home endowment into "Four Strengths; Four Possessions" service platform and service carrier can effectively solve these problems.

Third, it points out the single service supply main body problem. At present, it is an objective fact that community home endowment service supplies the main body government purchase services with relatively small investment, regulatory loophole; as a result, it is inevitably unable to guarantee the service quality. In addition, pension service volunteers are scarce. By the end of 2012, the number of volunteers in China was just above 30 million, which required no less than 20 hours a year, and the number of American volunteers was 3 times of our country. The gap is very wide and volunteer work for pension services in China is less. Include community home endowment work into "Four Strengths; Four Possessions"; either through streets departments, community party organizations at the grass-roots level can strengthen the organization and management of government purchase service personnel, but can also through the normalized, professional volunteer service team, provide a fixed, high quality of volunteer service.

Community home endowment in Qinhuangdao although has not yet been fully integrated into "Four Strengths; Four Possessions" mechanism of party construction, but from "Four Strengths; Four Possessions" achieved preliminary results in the global community work; we also can see the bright prospect in the future. The first is from heavier management to heavy service. By traditional management into active service, grass-roots party members and cadres go into the crowd and door-to-door service, party organizations' cohesion and appeal at the grass-roots level was further enhanced. The service platform and input are greatly strengthened. All the 2374 administrative villages in the city, community have built orderly and effective masses agent center with duty men 
and offices, which dealt with7403 complaint reporting matters, handled 57819 agent pieces. The group has a total of more than 3000 people to get into rural and community volunteer service and volunteered for more than 20000 hours. In addition, in 2013, village-level organization security funds reached every village every year above 40000 Yuan, some even up to 100000 Yuan. If community home endowment is blended among them, it will significantly improve the city's pension work construction level.

\section{Relying on the "Four Strengths; Four Possessions", Comprehensively Strengthen Community Home Endowment}

\section{A. Bring into full play the central role of grass-roots party organizations in community construction, strengthen the construction of relevant policy and system}

Further establish urban pension system with active participation of party committee leadership, government responsibility, and take community home endowment as the main body. In the name of the party committee, government, print materials on strengthening pension work, accelerating the development of pension industry, community home endowment as the main body of urban pension mode, and in which clear the core of the management system in grass-roots party organizations. As an important gripper of towns at the primary level, form community home endowment guaranteed good situation. On this basis, with policy system guarantee, form a complete set of the relevant provisions of the new village pension service facilities and give priority to transfer land, reduction of cost, give preferential home endowment service center on taxes, etc. Conditional region can take the way of subsidies to run home endowment institutions, and encourage and guide the families to participate in community home endowment. Stepping up efforts in supervising of family endowment service quality, on a regular basis for inspection or audit on an irregular basis, carry out questionnaire survey, and publish the results in the society.

B. Let grass-roots party organization to increase the positive role of community construction, and promote ascension of community home endowment hardware level

To do a good job of community home endowment, we need a lot of money. In the "Four Strengths; Four Possessions" creation work, combine with the party's mass line education practice, strive to solve the problem of common concern and need to solve, explore a shared win-win way of hardware. Through strengthening the construction of funds safeguard system, strengthen basic-level organization operating funds safeguard, increase financial input to the grassroots. Constructed community party member masses activity places, food, medical services, through simple design and system specifications (such as activity facilities classification according to the function, activity sites where the old and other residents use by time-sharing, dining at the same time for community residents at noon for home children "small table" service, etc.), and community home endowment is possible by perfect docking. In cases which do not affect other residents' usages, meet the needs of the pension, form a good situation of infrastructure sharing, and form harmony and win-win.

C. Play the unique advantages of a basic-level party organization in contacting and service to the masses and enrich community home endowment forms

Ruling party at the local level relies on countless grass-roots organization of the masses. Experience both at home and abroad tell us, to do a good job of pension, buy alone is not enough, we have enough emotional engagement, provide spiritual comfort for the elderly. This kind of emotion, on the one hand, is from the old man's relatives; on the other hand, it comes from volunteer service team. It reflects the care of party and the government, social for the elderly. Through the creation of "Four Strengths; Four Possessions", give full play to the important role of party organizations at grass-roots level, close ties with the masses, service to the masses are rich and powerful guarantees in the form of community home endowment. The political bureau of CPC central committee, secretariat Liu Yunshan pointed out in Anyang, Henan province, Xinyang research: "services to the people need both capital and ability, capital is their own good, and has a good stature, make a good example; 
power is to strengthen learning, improve ability, and practice service people's skills." Under the mechanism of "Four Strengths; Four Possessions", constantly improve the service ability and service level of the volunteer team.

\section{Play an excellent level of grass-roots party organizations in social management and with the introduction and standardization of social institutions can better participate in community home endowment}

Party organizations at the grass-roots level has an indispensable status to strengthen and improve the social management work, bears extremely arduous task and an important political responsibility of leadership, organization, guide and coordination of the jurisdictions of social management. Formed in the long-term practice, summarize a large number of effective good practices such as social security and maintaining stability "grid" management, etc. Pension is not only about people's livelihood, but is also about harmony and stability. Do a good job of community home endowment is an innovation of social management. The introduction, management, supervision, guidance and other important tasks of related projects are naturally fell upon the shoulders of party organizations at the grass-roots level. Based on full research, demonstrate, asking for advice, actively introduce social forces to run home endowment service agencies, regulate market operation, establish consultation mechanism, and at the same time improve the quality of service as much as possible to reduce disputes. When determining of enjoying relevant preferential policies of the elderly, strictly control and public information in a timely manner. Before pension service relationship, organize and supervise the two sides identified formal contract, and clear their respective rights and responsibilities. Coordinate to solve various contradictions and problems in a timely manner, make the liaison and mediator of both sides, avoid communication disharmony factors within the community, and do practical work to achieve the good thing.

\section{Acknowledgment}

Liu Jingjing, lecturer in Environmental Management College of China, master's degree. This article is one of Qinhuangdao 2013 science and technology research and development plan research results, the project number is: 201302A302.

Yuan Hejing, lecturer in Environmental Management College of China, master’s degree.

Contact: Liu Jingjing, Qinhuangdao city, Hebei province, 066004,

Telephone: 13463363495, email: 305338097 @qq.com

\section{References}

[1] The state council “"Twelfth Five-year’ plan for the development of Chinese aging development" [2011]. 28

[2] "What is a community party building", People's Daily, http://www.people.com.cn/

[3] Develop "Four Strengths; Four Possessions" activities to provide a strong organizational guarantee for taking the lead in opening up and catching up with development", Qinhuangdao Municipal Party Committee Organization Department, 2013.07.05 